\title{
XXXVII. Description of an apparatus for consuming firedamp in the mines without danger of an explosion:-Apparatus for re-lighting the miners' Davy
}

\section{Mr.J. Murray}

To cite this article: Mr. J. Murray (1817) XXXVII. Description of an apparatus for consuming firedamp in the mines without danger of an explosion:-Apparatus for re-lighting the miners' Davy, Philosophical Magazine Series 1, 50:233, 217-218, DOI: 10.1080/14786441708637763

To link to this article: http://dx.doi.org/10.1080/14786441708637763

$$
\text { 曲 Published online: } 27 \text { Jul } 2009 .
$$

$$
\text { Submit your article to this journal ๔ }
$$

\section{山 Article views: 2}


more, W. of the conflux, upon or even, in the whin, where it again disappears, by the over-lieing of Tyne-lottom limestone, which limestone may be traced to the W. up the same Beck, to High Cup Nick, where the stratum becones abrupt, as we descend to Dufton, and the whin, basseting underneath, and only about eight fathoms thick. It may also be observed at Great Rundle Beck, where the principal Jevel commences, and is drove upon it, to the mines at Dufton-fell.

I may further add, that the same great whinstone-bed occuss on the river Wear, near the town of Stanhope, in the county of Durham; but not so thick as at Caldron Snout.

I shall endeavour to answer the other queries in my next communication.

$$
\begin{aligned}
& \text { I an, sir, } \\
& \text { Gonigill, August 26, 1817. } \\
& \text { Wour most obedient servant, } \\
& \text { WESTRTH Forster. }
\end{aligned}
$$

XXXVII. Description of an Apparatus for consuming Firedamp in the Mines without Danger of an Explosion:Apparatus for re-lighting the Miners Davy. By $\mathrm{Mr}$. J. Murray,

\section{To Mr. Tilloch.}

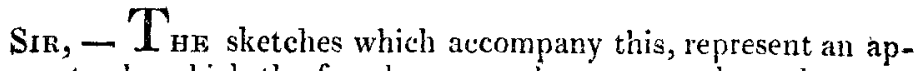
paratus by which the fire-damp may be consumed on the spot, in the mine, without fear of explosion; and an appendage to light the safe-lamp when extinguished. It is presumed that the descriptive account will be found sufficiently explanatory, and intelligible. If it should be objected to (fig. 1), that its size is too great,-it may be observed, that in the Air collieries safelamps on the principle of the wire-gauze have been used by Mr. Taylor three times the size of those constructed by Sir H. Davy.

1 did not find the plan I originally proposed to relight the lamp by any means mequivocal, when tried in the mine. This circumstance led to the present invention.

$$
\text { I am, sir, }
$$

Douglas, Isle of Man, Sep. 3, 1817.

J. Murray.

P. S.-The great increase of intensity which I discovered by exposing the Galvanic plates for a few minutes to the action of the atmosphere, prior to reimmersion into the cells, I have since repeated very often with the same uniform results. I shall be glad to see these in your next Number. 


\section{Description of the Figures.}

Fig. 2 (Plate III.) shows a cast-iron urn resting in a vessel of lime-water, or cream of lime, to absorb the carbonic acid gas formel. It is topped with two folds of wire-gauze at A. At $\mathrm{BBB}$ are three or moresockets, the orifices of which are covered with wire-gauze. In these sockets are fixed tubes of tin $\mathrm{C}$, which move up and down to any height like the slicling pipes of a perspective or opera glass; they terminate in a funnel-shaped orifice, or they may be jointed, to incline at any angle to receise the explosive medium for combustion. The "Davy" will be the index of the requisite height; the tubes should be raised within half an inch of the base of the fire-damp, floating on the roof, so that a due admixture of inflammable air and its supporter may enter the funnel of the tube, together.

Fig. 3 exhibits a view of the internal insulated wire-gauze, being that which imprisons the wick of flame; it does not touch the surrounding cast-iron case or urn, nor even the upper wiregauze, on its top. This cage may be made two or three folds. The lamip is fed by an oil cistern exterior to the urn, and a fold or two of wire-gauze in the communicating pipe will prevent any retrogression of flame where the eistern is to be supplied with oil. The wick may be of aslestos, which will never need renewal; and the lamp, first lighted, is screwed tight into the socket.

Fig. 4 represents the oil cistern of Dayy's safe-lamp with two separate wiaks. A exhibits ond of these vicks surrounded by a platinum cage. 1 the reserve, wick, with an ajpendage which serves at once to elevate the cap and depress the spiral platinum wire to ignite the wick; $a$ the cap attached to the axis $f$ by the wire $l$. $c$ a spring, that when at freedom reacts on the wire attached to the cap, which then falls and protects the wick, when not required; $d$ is a spiral platinum wire attached by $e$ to the axis $f$, which moves by a button exterior to the wire-gauze. The reserve wick is tipped with sulphur. When the wick of the lamp $\mathrm{A}$ is extinguished by reason of excess of fire-damp, the singular combustion of the platinum wire begins, and continues until there exists no longer any of the hydrocarbonate. The platinum wire before extinct becomes dull red; this will indicate an approach to the free atnosphere the moment after, by a semirotatory movement of the button, the cap is raised, and the top of the platinum brought in contact with the wick tipped with sulphur, which ignites it. 
Mr. Murmis Safty Furnace.

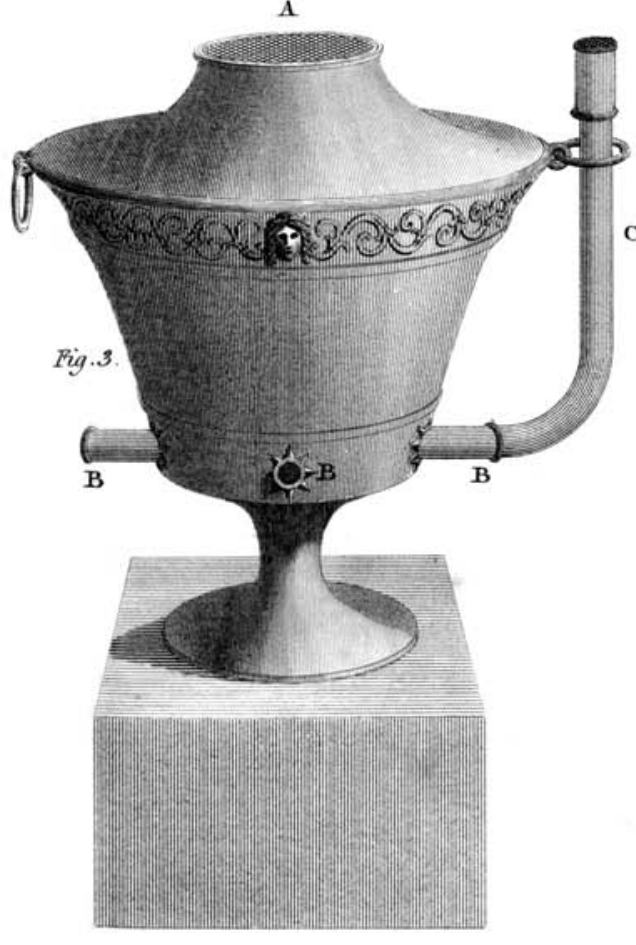

233.
Fig. 4
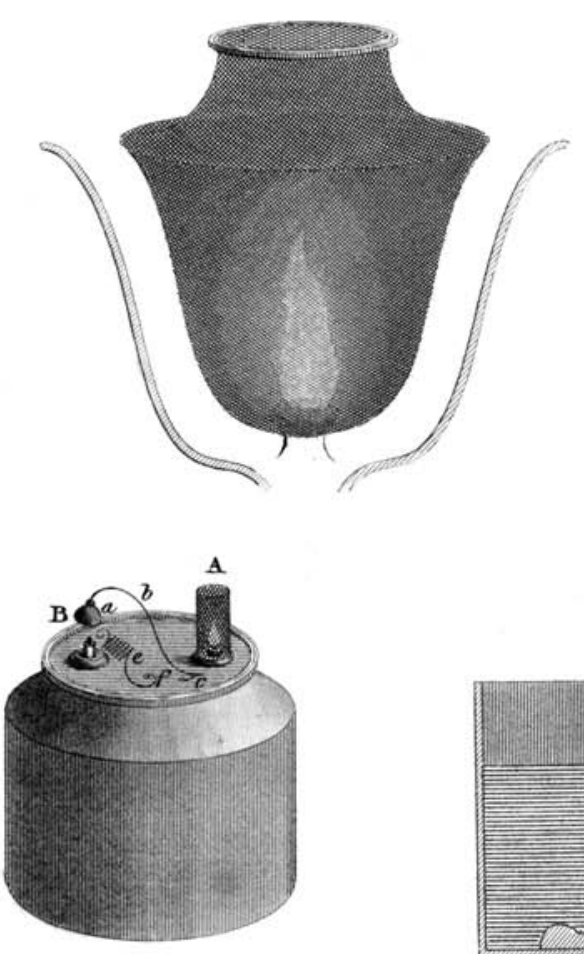

Fig. 5.

MrBakwells Safety Fumace.

Phil. Nag. Fol.InTl.II.

$a$ a

. 